\title{
The effects of sevoflurane and propofol on acoustic rhinometric measurements
}

\section{Sevofluran ve propofolüin akustik rinometrik ölçüimler üzerine etkisi}

\author{
Yildirim $\mathrm{S}^{1}$, Ozkan $\mathbb{F}^{2}$, Avci $\mathrm{O}^{3}$, Erkorkmaz $\mathrm{U}^{4}$
}

MD, Numune Hospital, Department of Anesthesiology, Sivas, ${ }^{2}$ Associated Professor,MD, Gaziosmanpasa University, School of Medicine, Department of Anesthesiology, Tokat, ${ }^{3} \mathrm{MD}$, Numune Hospital, Department of Anesthesiology, Sivas, ${ }^{4}$ Associated Professor ,MD, Gaziosmanpasa University, School of Medicine, Department of Biostatistics, Tokat

Corresponding author: Dr. Onur Avc1, Numune Hospital, Department of Anesthesiology, 58040, Sivas, TURKEY

E-mail: dronuravci@gmail.com

Received/Accepted: November 25,2016/February 01,2016

Conflict of interest: There is not a conflict of interest.

\section{SUMMARY}

Objective: The aim of the study was to compare nasal mucosal vasodilation induced by two different anesthetic used to provide controlled hypotension with the aid of acoustic rhinometry (AR).

Method: This study is prospective randomized clinical study. Fifty patients were randomized into propofol (Group P; $\mathrm{n}=25$ ) and sevoflurane (Group S; $\mathrm{n}=25)$ groups. During anesthesia induction, Group P received propofol $\left(2 \mathrm{mg} \mathrm{kg}^{-1} \mathrm{IV}\right)$ and Group $\mathrm{S}$ was administered sevoflurane at a minimal alveolar concentration of 6-8\%. Anesthesia was maintained with propofol (4 $\left.\mathrm{mg} \mathrm{kg} \mathrm{h}^{-1}\right)$ in Group P and 2\% sevoflurane in Group S. Both groups received the analgesic remifentanil at a dose of $0.025 \mu \mathrm{g} \mathrm{kg} \mathrm{min}{ }^{-1}$. Patients were performed nasal acoustic rhinometry (AR) measurements. Anesthetic doses were adjusted so as to ensure intraoperative hypotension by maintaining mean arterial pressure at $20-25 \%$ lower than the baseline value.

Results: In both groups, a significant difference was detected between AR and nasal minimal cross-sectional areas (MCA) measurements taken from the patients in the supine position, both during the preoperative period and at 30 minutes after the induction of anesthesia, but a meaningful decrease in MCA1 and MCA2 values after the induction of anesthesia was observed for both groups. In addition, differences in measurements taken before and after the induction of anesthesia were greater in amplitude for the sevoflurane group versus the propofol group.

Conclusions: Controlled hypotension induced using sevoflurane anesthesia might result in higher degrees of vasodilation relative to propofol anesthesia.

Keywords: acoustic rhinometry, vasodilation, sevoflurane, propofol, controlled hypotension.

\section{ÖZET}

Amaç: Bu çalışmanın amacı, akustik rinometri (AR) yardımıyla kontrollü hipotansiyon sağlamak için kullanılan iki anestezik ajanın nazal mukozal vazodilatasyon üzerine etkilerini karșılaștırmaktı.

Yöntem: Bu bir prospektif randomize klinik çalıșmadır. 50 hasta propofol (Grup P; n=25) ve sevofluran (Grup S; n=25) grupları olmak üzere iki gruba rastgele dağıtıldı. Anestezi indüksiyonu sirasında, Grup P propofol(2 $\left.\mathrm{mg} \mathrm{kg}^{-1} \mathrm{IV}\right) \mathrm{veGrup}$ S minimal alveolar konsantrasyonu \%6-8 olarak sevofluran ald1. Anestezi idamesi GrupP'de propofol(4 $\left.\mathrm{mg} \mathrm{kg} \mathrm{h}^{-1}\right)$ ile ve GrupS'de \%2 sevofluran ile sağlandi. Her iki gruba da $0.025 \mu \mathrm{g} \mathrm{kg} \mathrm{min}{ }^{-1}$ dozunda remifentanil analjeziği verildi. Hastalara nazal akustik rinometri (AR) ölçümleri yapıldı. Anestezik dozları, ortalama kan basıncı baz değerlerinin \%20-25'i olacak şekilde ayarland1.

Bulgular: Her iki grupta da hem preoperative süre boyunca hem de anestezi indüksiyonundan 30 dakika sonra, supin pozisyondaki hastalardan alınan AR ve nazal minimal çapraz kesit alanı (MCA) ölçümleri arasında anlamlı bir fark vardı. Ancak anestezi indüksiyonundan sonra MCA1 ve MCA2 de her iki grup için anlamlı bir azalma gözlendi. Ek olarak, anestezi indüksiyonundan önce ve sonra alınan ölçümler arasındaki fark, sevofluran grubunda propofol grubuna göre daha büyüktü.

Sonuç: Sevofluran kullanarak indüklenen kontrollü hipotansiyon, propofol ile uygulanan anesteziye göre daha yüksek derecede vazodilatasyona sebep olabilir.

Anahtar Sözcükler: akustik rinometri, vazodilatasyon, sevofluran, propofol, kontrollü hipotansiyon. 


\section{INTRODUCTION}

Controlled hypotension decreases cardiac output and/or systemic vascular resistance to acceptable limits from physiological and pharmacological perspectives. Abatement of bleeding with controlled hypotension ensures a clear surgical field, which allows safer and more rapid achievement of a procedure. Accomplishment of controlled hypotension using various maneuvers (positioning of the patient, positive pressure ventilation, administration of hypotensive agents) is termed 'hypotensive anesthesia'. To achieve hypotensive anesthesia, various agents such as volatile anesthetics, sympathetic antagonists, sodium nitroprusside, nitroglycerine, hydralazine, etc. can be used ${ }^{1,2}$.

The hemostatic efficacy of the hypotensive anesthetic technique applied depends on its ability to induce hypotension and minimal vasodilation in the surgical field. The degree of vasodilation achieved by various hypotensive anesthetic techniques might also predict the amount of possible bleeding from the surgical field. The noninvasive and pain-free acoustic rhinometric method, which requires only minimal patient compliance, is a reliable and precise quantitative analysis capable of assessing vascular changes and the degree of vasodilation in the nasal mucosa. This study differs from other similar investigations in that it is based on an objective evaluation of the degree of vasodilation induced in nasal mucosa by controlled hypotension with the aid of anesthetics.

The aim of this study was to compare the degree of vasodilation induced in nasal mucosa by controlled hypotension using propofol - remifentanil or sevoflurane - remifentanil combinations with the aid of quantitative acoustic rhinometric method.

\section{MATERIAL AND METHODS}

\section{Patients and groups}

After approval by the Institutional Ethics Committee (No:30.2.GOU.01 and Date: 05-092009) and acquisition of patients' informed consent, American Society of Anesthesiology (ASA) physical status I-II, 54 patients aged 18-65 years who had been referred to the outpatient clinic of the department of otorhinolaryngology for head and neck surgery were included in the study. Patients with diabetes, endocrine or metabolic disorders; morbid obesity (body mass index (BMI) $>40 \mathrm{~kg} / \mathrm{m}^{2}$ ); hypertension; hepatic dysfunction; known or suspected drug allergies; bleeding diathesis; severe respiratory failure; pregnant or lactating women; illicit drug addicts; alcoholics; anticoagulant users; those suffering from chronic and disturbing nasal stuffiness; and patients with a history of previous nasal operation(s), severe septal deviation, or other nasal pathologies such as nasal polyps, tumors, septal perforation, and rhinitis were excluded from the study. A sample size calculation was performed and found two groups of 27 patients each would be required to demonstrate a $25 \%$ difference with $\alpha=0.01, \beta=0.20$ and a power of 0.80 . The patients were randomized into two groups using computer-generated randomization schedule as Group $\mathrm{P}(\mathrm{n}=27$; propofol group) and Group $\mathrm{S}$ ( $\mathrm{n}=27$; sevoflurane group). Two patients from Group P and 2 patients from Group S were not included in the analysis because of high blood pressures. Demographic parameters and ASA categories of the patients were recorded.

\section{Measurements}

Rhinometric measurements were performed using a SRE 2100 device (Rhinometrics A/S, Lynge, Denmark), which emits signals as interrupted impulses in accordance with the criteria defined, as recommended by the Acoustic Rhinometry (AR) Standardization Committee. In an AR device, dimensions of the nasal cavity are measured using an acoustic echographic technique. From the curves obtained, various cross-sectional areas and volumes of the nasal cavity can be calculated. Acoustic rhinometry is method in which audible sound waves are directed to the nasal cavity and local acoustic impedances gathered from different cross-sectional areas are plotted as a curve describing the cross-sectional area of the nasal cavity as a function of distance from the nostrils. $\mathrm{AR}$ is able to detect nasal obstruction and its temporary or permanent reasons. AR is very fast in comparison to conventional methods and requires minimal patient cooperation. Since numeric values are provided, it is possible to compare different measurements. Although single measurement takes 8 milliseconds, complete procedure time is around 20 seconds $^{3}$. Obstructions in the nasal cavity are presented as notches in the rhinogram. Each notch represents a different anatomical area and these anatomic areas are called as "minimal crosssectional areas (MCA)". The first notch of the curve (Isthmus nasi notch, I-notch) represents the isthmus nasi (valve region). The second notch (Conchal notch, C-notch) corresponds to the head of the inferior turbinate and the anterior part of the septum. AR shows the changes in nasal cavity and its macrovascular coat in different conditions as quantitative values. AR is used for follow up after treatment of patients with allergic rhinitis, vasomotor rhinitis and evaluation the response of nasal mucosal provocation. (In terms of detecting mucosal changes, AR is more sensitive in lower 
doses when compared to the rhinomanometry $)^{4}$. It has been shown in the studies performed with histamine and bradykinin that MCAs decreased dose dependently ${ }^{5,6}$. AR shows the situation of nasal components before and after treatment clearly ${ }^{7}$ and it is useful for measuring nasal valve area ${ }^{8}$. AR can direct treatment by detecting which pathology and how much is taking part in both macrovascular and structural nasal obstructions. Although cross-sectional area examination is the most reliable parameter in nasal congestion studies $^{5}$, this reliability is decreasing from nares to choanas.

Cross-sectional areas, at distances from the nostril entrance to a previously defined cephalic point, and volumes of the nasal cavity were calculated from plotted curves using a 2.6 version of the Rhinoscan program (Rhinometrics A/S, Lynge, Denmark). For every new measurement day, a initialization procedure was implemented to calibrate the device so as to avoid technical errors. Before any application on the patient, the accuracy of measurements was tested using a "standard nose model" provided with the device.

The research fellows applying AR were blinded to group allocation. All measurements were obtained in the same room at ambient temperature $\left(18^{\circ} \mathrm{C}\right)$. For the measurements, conic probe tips of the same size, especially designed for right and left nostrils, were used. A thin layer of gel was applied on the tip of the probe of appropriate size, on the sides of the probe in contact with the nasal cavities, and on the nasal wings. The nasal tube was held at 45 degrees to the intersection line between the base of the nasal aperture priformis and the tragus. Then, the patient was asked to open his/her mouth and breathe slowly by mouth. Meanwhile, when the green light was on, which indicates the reliability of the measurement, three consecutive measurements were performed, and the results were plotted. Values obtained from these three curves were recorded as baseline values. The patients were brought into a relatively noiseless room the night before the operation, and they lied down in a supine position for approximately 30 minutes to accommodate to the environment, then baseline measurements were taken from both nostrils. On the day of the operation, one hour before entering the operating suite, the patients were given an IV isotonic $0.9 \% \mathrm{NaCl}\left(10 \mathrm{ml} \mathrm{h}^{-1}\right)$ infusion was started and it was maintained in the operating room. Heart rates (HRs), systolic (SBP) and diastolic (DBP) blood pressures, mean arterial pressures (MAP), and peripheral blood oxygen saturations $\left(\mathrm{SpO}_{2}\right)$ of the patients were noninvasively monitored (Siemens SC 7000 modular monitor, ENG) at 5 minute- intervals. The mean values of the three SBP, DBP, and MAP measurements obtained within 1 hour after premedication were accepted as baseline values. Before induction of anesthesia, both groups received remifentanil at an IV bolus dose of $1 \mu \mathrm{g}$ $\mathrm{kg}^{-1}$. Induction of anesthesia was achieved with 2 $\mathrm{mg} \mathrm{kg}{ }^{-1}$ propofol IV bolus for Group P, and 6-8 \% sevoflurane inhalation for Group $\mathrm{S}$. The patients received IV rocuronium $\left(0.5 \mathrm{mgkg}^{-1} \mathrm{iv}\right)$ after the establishment of mask ventilation was confirmed. After allowing time for motor paralysis to occur, endotracheal intubations were performed. For the maintenance of anesthesia, both groups received a $50 \% \mathrm{O}_{2}+50 \%$ air mixture and $0.025 \mu \mathrm{g} \mathrm{kg} \mathrm{m^{- }}$ ${ }^{1}$ remifentanil as a continuous infusion. In Group P, the propofol infusion was started at a dose of $4 \mathrm{mg}$ $\mathrm{kg} \mathrm{h}^{-1}$; however, in Group $\mathrm{S}$, the sevoflurane concentration was reduced to $2 \%$ and inhalations were maintained according to the patients' responses to treatment. Mechanical ventilation was performed so as to maintain tidal volume at $8 \mathrm{ml}$ $\mathrm{kg}^{-1}$, and respiratory rate at 10 per minute.

To achieve controlled hypotension, drug dosages were adjusted to less than $20-25 \%$ of the baseline values, taking care not to decrease preoperative MAP below $55 \mathrm{~mm} \mathrm{Hg}$. To attain targeted blood pressures, the inhalation rate of sevoflurane was adjusted to $1-3 \%$ per hour, while the infusion of propofol was set at a rate of $4-12 \mathrm{mg} \mathrm{kg} \mathrm{h}^{-1}$. At 30 minutes after the induction, in compliance with sterile conditions and in a noiseless environment, nasal cross-sectional areas were measured by AR, and the values obtained were evaluated as vasodilatory responses of the patients to the anesthetic methods they received.

Patients who could not attain required blood pressure values despite dose adjustments were evaluated for the last time before rhinometry, and subsequently excluded from the study. These patients were assessed for undesirable hypotension or hypertension, and medical interventions were instituted to achieve desirable levels of BP according to routine practices.

\section{Statistical Analysis}

Results obtained during the study were statistically analyzed using SPSS (Statistical Package for Social Sciences for Windows 15.0). For data retrieved, descriptive statistical methods (means, standard deviation) for intergroup comparisons of numerical variables, Student's $t$ test for intragroup comparisons of parameters and for qualitative comparisons, chi-square test and Fisher's exact chi-square tests were employed. AR results obtained from the patients in the supine position, 
both preoperatively and after induction of anesthesia, were assessed statistically. The results of mean changes were calculated per subject. The results were evaluated within 95\% confidence intervals, and $\mathrm{p}<0.05$ was considered significant. Demographics, SBP, DBP and MAP estimates of the patients were tabulated, while MCA1 and MCA2 values were presented as graphics.

\section{RESULTS}

A total of 50 patients were included in the study. 2 patients of each group were excluded due to intraoperative hypertension. No difference was found between two groups about age, body weight, height, and BMI (Table 1).

Table 1. Demographic characteristics and ASA physical status of patients

\begin{tabular}{lcccc}
\hline & $\mathbf{S}(\mathbf{n}=\mathbf{2 5})$ & $\mathbf{P}(\mathbf{n}=\mathbf{2 5})$ & $\mathbf{X}^{\mathbf{2}}$ & $\mathbf{P}$ \\
\hline Sex (Male/ Female) & $15 / 10$ & $12 / 13$ & 0.32 & 0.570 \\
Age (year) (Mean. \pm SD) & $43.08 \pm 15.17$ & $42.64 \pm 12.41$ & 0.11 & 0.911 \\
Weight (kg) (Mean.. SD) & $72.04 \pm 13.10$ & $73.24 \pm 13.92$ & 0.31 & 0.755 \\
Height (cm) (Mean.. SD) & $163.80 \pm 8.63$ & $166.24 \pm 8.43$ & -1.01 & 0.317 \\
BMI (Mean.. SD) & $26.95 \pm 5.19$ & $26.57 \pm 5.31$ & 0.26 & 0.798 \\
ASA (I/II) & $14 / 11$ & $19 / 6$ & 1.43 & 0.232 \\
\hline
\end{tabular}

Differences between MAP values calculated individually for each measurement period for Groups $\mathrm{S}$ and $\mathrm{P}$ were statistically significant. The firstly measured MAPs in Groups $\mathrm{S}$ and $\mathrm{P}$ were significantly higher than all other MAP estimates $(\mathrm{p}<0.001$, and $\mathrm{p}<0.001$, respectively). Although in both groups, significant changes in MAP values during procedures were observed, these variations were comparable in Groups S and P (Table 2).

Table 2. Comparison of mean arterial pressures (MAP) between two groups

\begin{tabular}{ccccc}
\hline Periods & $\begin{array}{c}\mathbf{S}(\mathbf{n}=\mathbf{2 5}) \\
\text { Mean } \pm \text { SD }\end{array}$ & $\begin{array}{c}\mathbf{P}(\mathbf{n}=\mathbf{2 5}) \\
\text { Mean } \pm \text { SD }\end{array}$ & $\mathbf{t}$ & $\mathbf{P}$ \\
\hline Baseline & $95.76 \pm 11.11$ & $98.88 \pm 9.54$ & -1.07 & 0.060 \\
5. min. & $74.00 \pm 9.11$ & $79.00 \pm 11.00$ & -1.75 & $\mathbf{0 . 0 0 8}$ \\
10. min. & $72.04 \pm 6.06$ & $73.92 \pm 6.51$ & -1.06 & $\mathbf{0 . 0 1 4}$ \\
15 min. & $71.76 \pm 5.70$ & $71.92 \pm 4.65$ & -0.11 & 0.075 \\
20. min. & $72.44 \pm 4.94$ & $70.96 \pm 4.34$ & 1.13 & 0.091 \\
25. min. & $71.24 \pm 7.34$ & $71.76 \pm 5.48$ & -0.28 & 0.189 \\
30. min. & $70.08 \pm 7.12$ & $70.52 \pm 5.68$ & -0.24 & $\mathbf{0 . 0 0 7}$ \\
35. min. & $69.84 \pm 7.10$ & $71.88 \pm 4.48$ & -1.22 & $\mathbf{0 . 0 2 0}$ \\
\hline \multicolumn{5}{c}{${ }^{*} \mathrm{~F}=53.40, \mathbf{p}<\mathbf{0 . 0 0 1}$} \\
& ${ }^{*} \mathrm{~F}=1.42, \mathrm{~F}=64.85, \mathbf{p}<\mathbf{0 . 0 0 1}$ & & \\
\hline
\end{tabular}

${ }^{*}$ F: Friedman Two-Way Analysis of Varians test result of comparison among 8 measures within group Min.: Minutes, S: Sevoflurane group, P: Propofol group

Preanesthetic measurements of right and left MCA1, and also mean MCA1 performed while the patients were in the supine position, did not differ significantly between Groups S and P. However, a statistically significant difference was seen between Groups $\mathrm{S}$ and $\mathrm{P}$ for right and left nose MCA1, and also for mean MCA1 measurements performed at 30 . minute of anesthesia $(p=0.012$, $p=0,011, p=0,002$ respectively). Each one of the three MCA1 values measured in Group $\mathrm{S}$ after the induction of anesthesia was significantly lower than the corresponding values of Group $P$ (Table 3). Percentage changes are shown during the operationMCA1values (Figure 1). 
Table 3.MCA1 data

\begin{tabular}{lllll}
\hline Nasal MCA1 & Periods & $\begin{array}{l}\text { Group S } \\
(\mathrm{n}=25) \\
\text { Mean } \pm \text { SD }\end{array}$ & $\begin{array}{l}\text { Group P } \\
(\mathrm{n}=25) \\
\text { Mean } \pm \text { SD }\end{array}$ & P \\
\hline Right nasalcavity & Preanesthetic & $0.47 \pm 0.15$ & $0.47 \pm 0.19$ & 0.867 \\
& 30 min.afterinduction & $0.30 \pm 0.13$ & $0.43 \pm 0.20$ & $\mathbf{0 . 0 1 2}$ \\
\hline Leftnasalcavity & Preanesthetic & $0.43 \pm 0.19$ & $0.48 \pm 0.18$ & 0.354 \\
& 30 min.afterinduction & $0.31 \pm 0.16$ & $0.44 \pm 0.20$ & $\mathbf{0 . 0 1 1}$ \\
\hline Mean & Preanesthetic & $0.45 \pm 0.15$ & $0.48 \pm 0.14$ & 0.485 \\
& 30 min.afterinduction & $0.30 \pm 0.12$ & $0.43 \pm 0.16$ & $\mathbf{0 . 0 0 2}$ \\
\hline
\end{tabular}

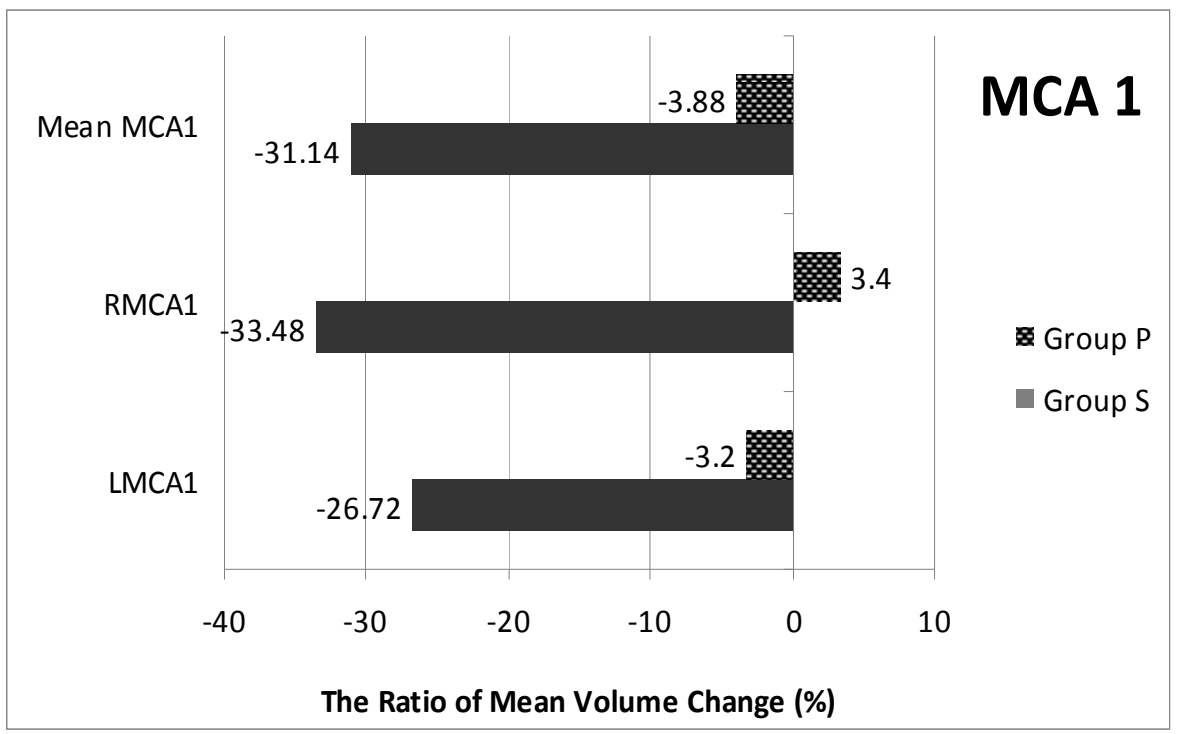

Figure 1: Changes of the right, left, mean MCA1 values according to acoustic rhinometry measurements. MCA; Minimal cross-sectional area

Pre-anesthetic measurements of right and left MCA2, and also mean MCA2 performed while the patients were in the supine position, did not differ significantly between Groups $S$ and $P(p>0.05)$. However, a statistically significant difference was seen between Groups S and P for right and left nose MCA2, and also for mean MCA2 measurements performed at $30^{\text {th }}$ minute of anesthesia $(\mathrm{p}<0.05$, $p=0.024, p=0,014$ respectively). Each one of the three MCA2 values measured in Group S after the induction of anesthesia was significantly lower than the corresponding values of Group $P$ (Table 4). Percentage changes are shown during the operation MCA2 values (Figure 2). 
Table 4.MCA2 data

\begin{tabular}{lllll}
\hline Nasal MCA2 & Periods & $\begin{array}{l}\text { Grup S } \\
(\mathrm{n}=25) \\
\text { Mean } \pm \text { SD }\end{array}$ & $\begin{array}{l}\text { Grup P } \\
(\mathrm{n}=25) \\
\text { Mean } \pm \text { SD }\end{array}$ & P \\
\hline Right nasalcavity & Preanesthetic & $0.42 \pm 0.18-1.11$ & $0.49 \pm 0.25$ & 0.274 \\
& 30 min.afterinduction & $0.26 \pm 0.18-1.96$ & $0.37 \pm 0.25$ & 0.056 \\
\hline Leftnasalcavity & Preanesthetic & $0.41 \pm 0.20$ & $0.53 \pm 0.27$ & 0.093 \\
& 30 min.afterinduction & $0.25 \pm 0.17-2.34$ & $0.42 \pm 0.31$ & $\mathbf{0 . 0 2 4}$ \\
\hline Mean & Preanesthetic & $0.42 \pm 0.13-2.12$ & $0.51 \pm 0.17$ & $\mathbf{0 . 0 3 9}$ \\
& 30 min.afterinduction & $0.25 \pm 0.14-2.57$ & $0.40 \pm 0.24$ & $\mathbf{0 . 0 1 4}$ \\
\hline
\end{tabular}

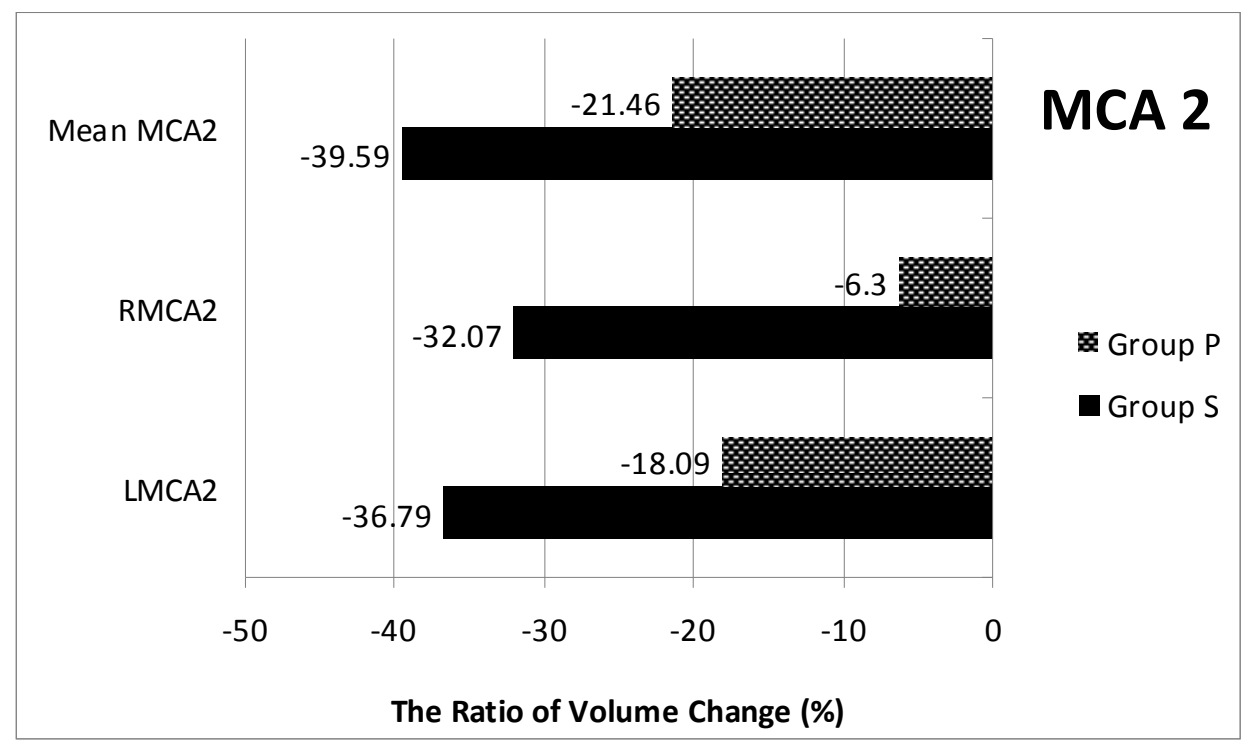

Figure 2: Changes of the right, left, mean MCA2 values according to acoustic rhinometry measurements. MCA; Minimal cross-sectional area

On preoperative intragroup assessments of Group S, MCA1 and MCA2 values obtained while the patients were in the supine position, from the right and left nose, and also mean MCA1 and MCA2 values, were statistically significantly higher than those measured at $30^{\text {th }}$ minute of anesthesia $(p<0.001, p<0.001$, and $p<0.001$, respectively) and $(\mathrm{p}<0.001, \mathrm{p}<0.001$, and $\mathrm{p}<0.001$, respectively). Shows the percentage of the total change in values during the operation MCA1 and MCA2 (Figure 3). 


\section{The Sum of MCA 1 and MCA 2}

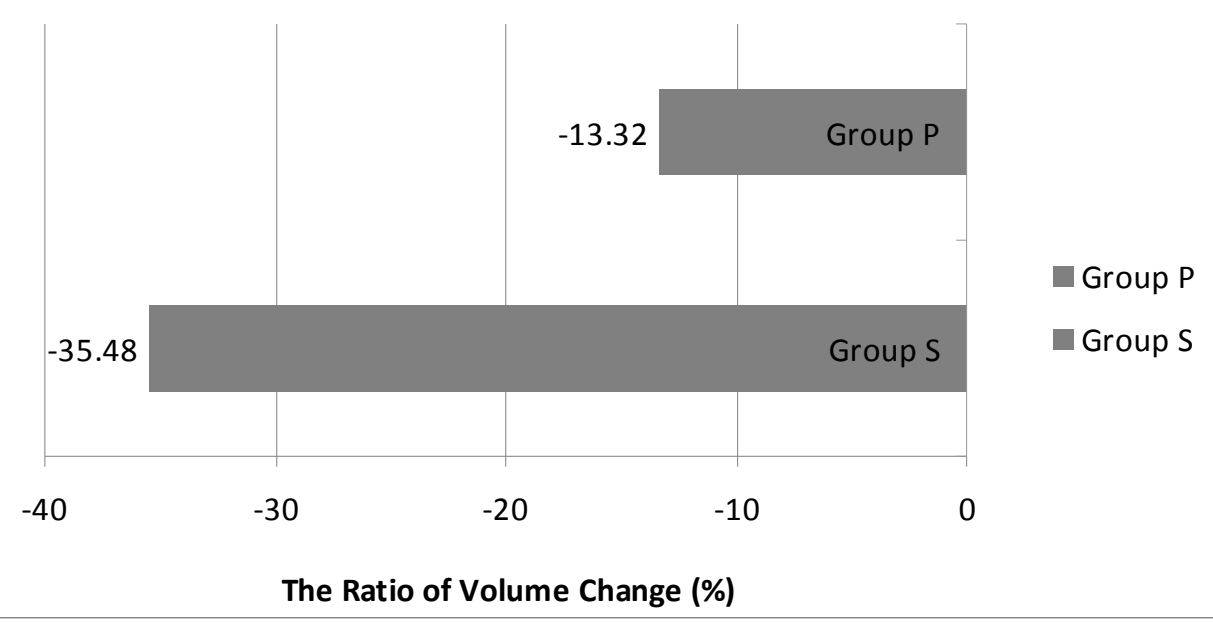

Figure 3: As percent of total change values during the operation to show MCA1 and MCA2. MCA; Minimal crosssectional area

\section{DISCUSSION}

Controlled hypotension diminishes blood loss, allows better visualization of the surgical field, and ensures surgical interventions are performed safely, easily, and over a short time. Achievement of these levels using various maneuvers (positioning of the patient, positive pressure ventilation, usage of hypotensive agents, etc.) are termed hypotensive anesthesia. This technique can acceptably lead to a nearly $50 \%$ decrease in blood loss1,2. Nowadays, microscopic techniques are used in many surgical interventions. Besides maintenance of crucially important hemostasis in microsurgical interventions, positioning maneuvers performed by the surgeon should be observed carefully, and every measure should be taken to facilitate these maneuvers. Since surgical interventions requiring microscopic guidance cannot even tolerate minor bleeding, which can complicate working in the operative field, to obtain a bloodless field, the patient's blood pressure should be decreased in a controlled way.

Since propofol possesses the characteristics of an ideal intravenous induction agent, it is used in bolus or infusion forms in ICUs in combination with oxygen, nitrous oxide, and opioids, with the intention of sedation in general anesthesia ${ }^{9,10}$. Though anesthetic practices in adults are generally realized rapidly and safely using intravenous agents like propofol, mask induction of anesthesia might be preferred to avoid the adverse effects of IV induction, such as hypotension, anaphylaxis, and apnea, and also to provide comfortable inductions for patients and children who fear intravenous procedures ${ }^{11-14}$. Sevoflurane does not have a disgusting odor, but rather possesses a pleasant smell for inhalation by conscious patients. Therefore, its odor does not result in any adverse effects. Satoru et al. hemodynamically compared mask induction of anesthesia using sevoflurane, isoflurane, halothane, and enflurane, and demonstrated sevoflurane and halothane as the optimal agents to be used for mask induction ${ }^{15}$. In a study where induction of anesthesia using sevoflurane and propofol was compared, sevoflurane was indicated as a probable alternative in place of IV agent ${ }^{16}$. In some studies where induction or maintenance of anesthesia with sevoflurane or propofol were compared, sevoflurane had emerged as an alternative in lieu of propofol ${ }^{17,18}$. Remifentanil is a preferred opioid both in total intravenous anesthesia (TIVA), and in balanced inhalation anesthesia, for the following reasons: its effects start and disappear rapidly, it provides deep intraoperative analgesia for shorter or longer periods according to needs, and it provides a very easily titrable dose without any concern for delayed recovery from anesthesia ${ }^{19,20}$. In the studies conducted, though all opioids demonstrate similar effects in achieving bloodless surgery, remifentanil manifested comparatively improved intraoperative hemodynamic stability against surgical stress ${ }^{21,22}$. In a study with a similar design to ours, in tympanoplasty operations, remifentanil infusions $(0.2-0.5 \mu \mathrm{g} \mathrm{kg}$ min-1) were administered. Bolus doses of $1 \mu \mathrm{g} \mathrm{kg}-1$ of the drug and propofol at a dose of $120 \mu \mathrm{g} \mathrm{kg} \mathrm{min}-1$ were used in combination with sevoflurane, whose dose was adjusted so as to attain end-expiratory 
concentration of $2 \%$, and it was emphasized that both methods provided controlled hypotension without the need for an additional hypotensive agent, and a bloodless surgical field due to a decrease in blood flow supplying the middle ear was achieved with resultant improved surgical conditions ${ }^{22}$. In a study that aimed to decrease the amount of bleeding by controlled hypotension, the authors demonstrated that a propofol-remifentanil combination achieved more effective hemostasis than aisoflurane-fentanyl combination in 64 patients undergoing functional endoscopic sinus surgery, and time to attain MAP was similar in both groups $^{23}$. In our study, with either agent, the desired levels of blood pressure were reached within 5 minutes. Besides, no significant difference was seen between the groups as to SBP, DBP, MAP, and heart rates measured at baseline within the first 5 minutes after establishment of intubation.

Acoustic rhinometry (AR) is an objective diagnostic test used in otorhinolayngology procedures $^{24}$. In AR, acoustic signals are delivered into the nasal cavity, and the location and diameter of narrowed nasal segments can be evaluated quantitatively using the estimates for intensity, phase, and delay times of the signals reflected by the nasal cavities, and these parameters can be demonstrated in an acoustic rhinogram. The effects of expedited maxillary augmentation on nasal cavities of 29 children aged between 7-10 years, with maxillary atresia, were demonstrated, and the authors stated that AR measurements of MCA1 and MCA2 values did not differ, while nasal resistance decreased somewhat ${ }^{25}$. A retrospective study aimed to reveal clinical correlations between AR and CT methods, and concluded that CT screening tests that correlated with a clinical diagnosis had a somewhat better diagnostic value relative to AR, without any significant differences between them ${ }^{26}$. Roithmann et al. $^{27}$ compared AR measurements obtained from subjects in the supine and seated positions in 10 asymptomatic individuals, and 10 patients with allergic rhinitis, and in both groups, minimal cross-sectional areas and total nasal volumes measured in the supine position were relatively lower. In our study, since measurements performed in accordance with AR guidelines did not bear any relationship to anesthesia, the results obtained were not included in the study analysis. However, mean MCA1 and MCA2 measurements performed at 30 Minutes, in the seated position, yielded higher, albeit insignificant values when compared with the corresponding results obtained at 30 minutes in the supine position.
Despite the numerous acoustic rhinometric studies resembling the designs of the above-mentioned ones, a trial evaluating controlled hypotension and vasodilation induced by anesthetic agents using AR methods is lacking. In this study, vasodilations achieved with two different anesthetic agents were compared and evaluated quantitatively using AR. In our study, MCA values decreased with hypotensive anesthesia, which is due to a reduction in the volume of the nasal cavity as a result of vasodilation. This reduction was greater with sevoflurane anesthesia. The amount of surgical bleeding depends on the degree of hypotension and the vasodilation effect of the instituted agent on the region in question. We did not evaluate surgical site bleeding; however, various studies have demonstrated that bleeding is more abundant during sevoflurane anesthesia when compared with propofol $^{28-35}$. Our study has revealed that sevoflurane induces relatively greater vasodilation in the nasal mucosa, which explains why more severe bleeding is encountered during sevoflurane anesthesia.

This study demonstrated that a hypotensive anesthetic technique realized using propofol induces lesser degrees of vasodilation in nasal mucosa when compared with sevoflurane.

\section{REFERENCES}

1. Morgan GE, Mikhail MS, Murray MJ Hypotensive Agents In: Morgan GE Jr, Mikhail MS, Murray MJ (Eds). Clinical anesthesiology (Ed 3). New York: McGraw-Hill 2002; 231-2.

2. Monk CR and Milard RK Controlled Hypotension. In Cedric Prys-Roberts and Burnell R. Brown Jr (Eds): International practice of anesthesia. Oxford: Butterworth-Heinemann 1996; $1-11$

3. Djupesland PG, Lyholm B Technicaagabeylities and limitations of acoustic rhinometryoptimised for infants. Rhinology Sep 1998; 36: 104-13.

4. Riechelmann $\mathrm{H}$, Rheinheimer $\mathrm{MC}$, Wolfensberger M Acousticrhinometry in preschool children.CliOtolaryngol 1993; 18: 272-7.

5. Roitmann R, Shpirer I, Cole P, Chapnik J, Szalai JP, Zamel N. The role acoustic rhinometry in nasal provocation testing. Ear Nose Throat J 1997; 76: 747-52.

6. Austin CE, Foreman JC Acoustic rhinometry compared with posterior rhinomanometry in the measurement of histamine-and bradykinininduced changes in nasal airway patency. Br. J ClinPharmacol 1994; 37: 33-7.

7. Passali D, Mezzedimi C, Passali GC, Nuti D, Bellussi L The role of rhinomanometry, acoustic rhinometry and mucociliary transport time in the 
assessment of nasal patency. Ear Nose Throat $\mathrm{J}$ 2000; 79: 397-400.

8. Roitmann R, Cole P, Chapnik J, Barreto SM, Szalai JP, Zamel N Acoustic rhinometry, rhinomanometry, a and the sensation of nasal patency: a correlative study. J Otolaryngol 1994; 23: 454-8.

9. MacPherson RD Pharmaceutics for the anaesthetist.Anaesthesia 2001; 56: 965-79.

10. Masaki $Y$, Tanaka $M$, Nishikawa $T$ Physicochemical compatibility of propofollidocaine mixture.AnesthAnalg 2003; 97: 1646-51. 11. Patel S, Goa KL Sevoflurane, a review of its pharmacodynamic and pharmacokinetic properties and its clinical use in general anesthesia. Drugs 1996; 51: 658-700.

12. Yasuda N, Lockart SH, Eger EI 2nd, Weiskopf RB, Liu J, Laster M, Taheri S, Peterson NA Comparison of kinetics of sevoflurane and 1soflurane in humans. AnesthAnalg 1991; 72: 31124.

13. Bito H, Ikeda K Closed-circuit anesthesia with sevoflurane in humans. Effects on renal and hepatic function and concentrations of breakdown products with soda lime in the circuit..Anesthesiology 1994; 80: 71-6.

14. Lerman J, Sikich N, Keinman S, et al The pharmacology of sevoflurane in infants and children.Anesthesiology 1994; 80: 814-24.

15. Satoru T, Hideaki $T$, Kenichi $N$, et al The effects of sevoflurane, isoflurane, halothane, and enflurane on hemodynamic responses during an inhaled induction of anaesthesia via a mask in humans. AnesthAnalg 1996; 82: 821-26.

16. Ti LK, Pua HL, Lee TL Single vital capacity inhalational anaesthetic induction in adultsisofluranevssevoflurane. Can J Anaesth 1998; 45: 949-53.

17. Lien CA, Hemmings HC, Belmont MR, et al A comparison: The efficacy of sevoflurane-nitrous oxide or propofol-nitrous oxide for the induction and maintenance of general anesthesia. $J$ ClinAnesth 1996; 8: 639-43.

18. Jellish SW, Lien CA, Fontenot HJ, et al The comparative effects of sevoflurane versus propofol in the induction and maintenance of anesthesia in adult patients. AnesthAnalg 1996; 82: 479-85.

19. Degoute CS, Ray MJ, Manchon $M$, et al Remifentanil and controlled hypotension; comparison with nitroprusside or esmolol during tympanopiasty. Can J Anaesth 2001; 48: 20-7.

20. Karabayirli S, Ugur KŞ, Demircioglu Rİ, Muslu B, Usta B, Sert H, Nebil Ark, Surgical conditions during FESS; comparison of dexmedetomidine and remifentanil, European Archives of Oto-Rhino-Laryngology 2017; 274: 239-45
21. Philip BK, Scuderi PE, Chung F, et al Remifentanil compared with alfentanil for ambulatory surgery using total intravenous anesthesia. The Remifentanil/Alfentanil Outpatient TIVA Group.AnesthAnalg 1997; 84: 515-21.

22. Degoute CS, Ray MJ, Gueugniaud PY, et al Remifentanil induces consistent and sustained controlled hypotension in children during middle ear surgery. Can J Anaesth 2003; 50: 270-6.

23. Tirelli G, Bigarini S, Russolo M, et al Total intravenous anesthesia in endoscopic sinüs-nasal surgery. Acta Otorhinolaryngology Italy 2004; 24 : $137-44$.

24. Numminen J, Dastidar P, Heinonen T, et al Reliability of acoustic rhinometry.Respir Med 2003; 97: 421-7.

25. Enoki C, Valera FC, Lessa FC, et al Effect of rapid maxillary expansion on the dimension of the nasal cavity and on nasal air resistance.Int $\mathrm{J}$ PediatrOtorhinolaryngol 2006; 70: 1225-30.

26. Mamikoglu B, Houser S, Akbar I, et al Acoustic rhinometry and computed tomography scans for the diagnosis of nasal septal deviation, with clinical correlation. Otolaryngol Head Neck Surg 2000; 123: 61-8.

27. Roithmann R, Demeneghi P, Faggiano R, et al Effects of posture change on nasal patency. Rev Bras Otorrinolaringol 2005; 71: 478-84.

28. Eberhart LH, Folz BJ, Wulf H, et al Intravenous anesthesia provides optimal surgical conditions during microscopic and endoscopic sinus surgery. Laryngoscope 2003; 113: 1369-73.

29. Beule AG, Wilhelmi $F$, Kühnei $T S$, et al Propofol versus sevoflurane: bleeding in endoscopic sinus surgery. Otolaryngol Head Neck Surgery 2007; 136: 46-50.

30. Chaaban MR, Baroody FM, Gottlieb O, Naclerio LM Blood loss during endoscopic sinus surgery with propofol or sevoflurane. JAMA Otolaryngol Head Neck Surg 2013; 139(5): 510-4 31. Mohammad H.Al-Bar ,Jose W. Ruiz , Roy R.Casiano Does total intravenous anesthesia provide significant blood loss reduction compared to inhalational anesthesia during endoscopic sinus surgery? Laryngoscope 2016; 126(9):1961-2

32. Ahn HJ, Chung SK, Dhong HJ et al Comparison of surgical conditions during propofol or sevoflurane anaesthesia for endoscopic sinus surgery. Br J Anaesth 2008; 100(1): 50-4

33. Suhitharan T, Sangeetha S, Kothandan H, Esther DU, Vui Kian Ho, Anesthetic techniques and haemodynamic control for Endoscopic Sinus Surgery: A retrospective analysis and review of literature, Egyptian Journal of Anaesthesia 2017; 33: 9-14 
34. Amorocho MC, Fat J, Anesthetic Techniques in Endoscopic Sinus and Skull Base Surgery, Otolaryngologic Clinics of North America, 2016; 49(3): 531-47
35. Pant H, Hemostasis in Endoscopic Sinus Surgery, Otolaryngologic Clinics of North America 2016; 49(3): 655-76 